\title{
Correlation Between Vocabulary Mastery and Arabic Debate Ability
}

\author{
Ana Taqwa Wati ${ }^{1, *}$ Nasita Dara Maula ${ }^{2}$ \\ ${ }^{1}$ Universitas Muhammadiyah Yogyakarta Arabic, Education Department Yogyakarta, Indonesia \\ ${ }^{2}$ Universitas Muhammadiyah Yogyakarta Arabic, Education Department Yogyakarta, Indonesia \\ *Email: ana_tw@umy.ac.id, maulanasitadara@gmail.com
}

\begin{abstract}
Speaking skills can express sounds or words to express thoughts in ideas, opinions, or feelings to other audiences. A debate is one of the most appropriate and strategic forums to develop thinking and speaking skills in education. This study aims to identify a correlation between vocabulary mastery of Arabic language debate in the Arabic language education study program and the inhibiting factors that affect the Arabic language education study program's Arabic language education study program besides vocabulary mastery. This research is a correlational descriptive quantitative research. In this study, the population and sample were 25 students of the Arabic Language Education Program UMY class A of 2018. The samples were determined using a non-probability sampling technique with a saturated sample technique. Data collection techniques used observation, interviews, and documentation, while data analysis used product-moment correlation. Based on the research results, there was a perfect correlation between vocabulary mastery and students' debate skills, with a correlation value of 0.866 and a sig value. ( 2 tailed) 0.000 . Inhibiting factors from the students' ability to Arabic language debate and vocabulary mastery were the material or theme factors in the debate, the debating participants' ability, the environment, and language.
\end{abstract}

Keywords: Arabic Debate, Correlation, Vocabulary Mastery

\section{INTRODUCTION}

Nowadays, the Arabic learning process in Indonesia has not shown satisfactory results. Arabic learning material is one of the learning materials that are less attractive to students from elementary to tertiary levels. This condition gives the impression that the Arabic language is more challenging to learn than the other languages, even though, as the largest Muslim population globally, Indonesian people should understand Arabic easily.

In Arabic learning, there are four levels of skill to which each other is related in both oral communication and written forms. The four skills are maharah al-istima '(listening skills), maharah kalam (speaking skills), maharahqiro'ah (reading skills), maharahkitabah (writing skills). The four maharahs are related to each other. Based on the various types of maharah, the purpose of learning Arabic is to use Arabic both in oral and in written form.

Learners must have a large vocabulary to master the four skills since vocabulary mastery is a person's main asset in communicating and disseminating ideas either in oral or written form. Vocabulary mastery is many words that a person knows and understands the meanings in language activities [1]. However, foreign language vocabulary, especially Arabic, is difficult for educators because of the differences between the language commonly used and the language studied. The differences among others lie in sound system (phonology), grammar structure (nahwu and shorof), vocabulary, word structure, and writing [2].

A debate is one of the most appropriate and strategic forums to develop thinking skills and speaking skills in education. It is also an area where a person shows his passion for communicating with his extensive vocabulary and an arena where someone defends his argument or opinion with his debate opponent. In education, a debate can be used as a valuable method to increase thinking and reflection to express opinions contrary to themselves [3]. In defending an argument during a debate, someone is challenged to think critically and quickly and have extensive knowledge and strong guidelines to strengthen their arguments. 
The Correlation of Vocabulary Mastery on the Ability of Arabic Debate in the Arabic Language Education Study Program, Universitas Muhammadiyah Yogyakarta. This research is correlational research focusing on the correlation results in two or more variables in a study. Besides identifying the correlation between the two in this study, it also discusses what factors can affect the students' debating ability of the Arabic language education study program apart from vocabulary mastery.

\section{METHOD}

This research is descriptive quantitative research using a quantitative method to determine the correlation value between vocabulary mastery and the Arabic debate's value. The researchers used a descriptive method to explain the factors influencing students in improving Arabic language debating skills apart from vocabulary mastery factors. This research belongs to correlation research. It is a type of research with problem characteristics in the form of a correlational relationship between two or more variables [4]. Furthermore, the researcher used two variables in the object of study. The first variable $(\mathrm{X})$ was vocabulary mastery, and the second variable (Y) was the ability to do debating in Arabic. The formula used in this research was the product-moment correlation formula:

$$
\begin{aligned}
& \mathbf{r}=\frac{n \sum x_{y^{-}}\left(\sum \mathrm{x}\right)\left(\sum y\right)}{\sqrt{\left\{n \sum x^{2}-\left(\sum x\right)^{2}\right\}\left\{n \sum y^{2}-\left(\sum y\right)^{2}\right\}}} \\
& \mathrm{n}=\quad \text { Total number of data pairs } \mathrm{X} \\
& \Sigma \mathrm{y}=\text { Total Number of VariableY } \\
& \Sigma \mathrm{x}^{2}=\quad \text { Quadrate of Total Number of } \\
& \text { Variabel X } \\
& \Sigma y^{2}=\quad \text { Quadrate of Total Number of } \\
& \text { Variable Y } \\
& \text { Exy } \quad=\quad \text { Multiplication } \\
& \text { Result of the Total Number of variable X } \\
& \text { dan Variabel Y [4]. }
\end{aligned}
$$

This correlation research aims to identify a relationship between the two variables and how far the correlation is between the variables studied. This type of research emphasizes the level of relationship provisions, which can also predict a problem.

In this study, the researchers collected the data from various parties in the study program:

1. Head of the Arabic language education study program at Universitas Muhammadiyah Yogyakarta for a research permit from the study department

2. Lecturers in the Munadhoroh course in the Arabic education study program determine the teaching and learning process when the Munadhoroh learning process was conducted

3. Students of class A Arabic education study program to obtain information directly about what factors influence students' Arabic debating skills apart from vocabulary mastery factors

4. The study program's administration section to obtain student data, study program profiles, and data on teachers and staff in the study program

The researchers' method of the data collection procedure to obtain the required data included: 1 . Observation, in this study, the researchers chose to use the type of unstructured observation. This observation aims to find out an aspect that other researchers went unnoticed; thus, the researchers could use these deficiencies to become the object of his research. Besides, researchers also used the observation to identify the facilities and infrastructure provided by the study program. 2. Interview, this method was a way for researchers to get explanations or answers from respondents directly [5]. In this study, the researchers used the interview method to obtain data and answers based on the second problem formulation. Researchers also used the interview method to obtain data from lecturers who taught Munadhoroh courses about how the Munadhoroh learning process in terms of teachers was conducted. 3. Documentation was a data collection method by re-viewing or re-recording existing data [6]. The researchers used this method to obtain students' vocabulary mastery scores and students munadhoroh scores from the lecturers who taught these subjects. Moreover, the researchers also used documentation to obtain a study program profile from the administration section.

The data analysis steps in this study consist of three stages: 1. Choosing data was a process in which the researchers sorted the data obtained and was considered necessary in the research process. 2. Displaying data, to facilitate data processing, the researchers displayed the data required to answer the first problem formulation using a table. To answer the second problem formulation, the researchers used a brief description. 3. Making conclusions was the final process in data processing carried out by researchers in this study. The researchers used the SPSS application to answer the formulation of the first problem in this study. In terms of the second problem formulation, the researchers made conclusions based on the interviews conducted with students or respondents previously determined.

\section{RESULT AND DISCUSSION}

In the result and discussion section, the researchers used two types in the data presentation, namely a quantitative to explain the correlation between vocabulary mastery and Arabic language debate skills, and the description to explain what factors hinder the ability to debate in the Arabic language apart from the vocabulary mastery factor. Collecting data about the vocabulary score and the 2018 students' Arabic language debate score was by requesting the data score given by the lecturer who taught the course. In terms of the inhibiting variable in the Arabic debate, the researchers used the interview method. Therefore, the researchers used the documentation method to obtain student vocabulary and debate scores 
and the correlation test to obtain the correlation value. The researchers also used the interview method to determine the inhibiting factors that students felt apart from the vocabulary mastery factor.

The researcher obtained data about the list of vocabulary values and the Munadhoroh course's value based on the researchers' data through the documentation method.

Table 1. Data for Vocabulary Score

\begin{tabular}{|c|c|c|c|}
\hline Number & $\begin{array}{l}\text { Student } \\
\text { Number }\end{array}$ & Name & Vocabulary \\
\hline 1 & 2018082001 & Elya Mawarni & 85 \\
\hline 2 & 2018082002 & $\begin{array}{l}\text { Autsaqani } \\
\text { Fllubudiyati }\end{array}$ & 80 \\
\hline 3 & 2018082003 & $\begin{array}{l}\text { Ahmad } \\
\text { Bahrum } \\
\text { Madoan }\end{array}$ & 95 \\
\hline 4 & 2018082005 & $\begin{array}{l}\text { Khitoh } \\
\text { Fatonah }\end{array}$ & 75 \\
\hline 5 & 2018082006 & $\begin{array}{l}\text { Umi Nur } \\
\text { Hidayah }\end{array}$ & 65 \\
\hline 6 & 2018082007 & $\begin{array}{l}\text { Nurarsyi } \\
\text { Nugrahawati }\end{array}$ & 80 \\
\hline 7 & 2018082008 & Khairunnisa & 75 \\
\hline 8 & 2018082009 & $\begin{array}{l}\text { Indra } \\
\text { Adisaputra }\end{array}$ & 90 \\
\hline 9 & 20180820010 & $\begin{array}{l}\text { Paramudita } \\
\text { Arbi Nugroho }\end{array}$ & 80 \\
\hline 10 & 20180820011 & $\begin{array}{l}\text { Syifa Miftahul } \\
\text { Jannah }\end{array}$ & 75 \\
\hline 11 & 20180820012 & $\begin{array}{l}\text { Laura } \\
\text { Oktarianti } \\
\text { Nasution }\end{array}$ & 70 \\
\hline 12 & 20180820013 & $\begin{array}{l}\text { Irawati } \\
\text { Khoviva Duru }\end{array}$ & 75 \\
\hline 13 & 20180820014 & Zyubhaida & 90 \\
\hline 14 & 20180820018 & $\begin{array}{l}\text { Fikri Aulia } \\
\text { Madani }\end{array}$ & 80 \\
\hline 15 & 20180820019 & $\begin{array}{l}\text { Eza Qurnia } \\
\text { Hayati }\end{array}$ & 80 \\
\hline 16 & 20180820020 & $\begin{array}{l}\text { Sari Arya } \\
\text { Ningrum }\end{array}$ & 75 \\
\hline 17 & 20180820021 & $\begin{array}{l}\text { Moh Fikri } \\
\text { Akbar Arasy }\end{array}$ & 0 \\
\hline 18 & 20180820022 & Duratul Jinan & 70 \\
\hline 19 & 20180820025 & $\begin{array}{l}\text { Rahmawati } \\
\text { Indriyani }\end{array}$ & 80 \\
\hline
\end{tabular}

\begin{tabular}{|l|l|l|l|}
\hline 20 & 20180820027 & Farah Tazkia & 50 \\
\hline 21 & 20180820028 & Linda Wati & 85 \\
\hline 22 & 20180820029 & $\begin{array}{l}\text { Urfa Zuyina } \\
\text { Alfarisi }\end{array}$ & 85 \\
\hline 23 & 20180820030 & $\begin{array}{l}\text { Muhammad } \\
\text { Maulud } \\
\text { Ikhsan } \\
\text { Nabawi }\end{array}$ & 80 \\
\hline 24 & 20180820031 & $\begin{array}{l}\text { Rizal Yusuf } \\
\text { Hanifa }\end{array}$ & 65 \\
\hline 25 & 20180820033 & $\begin{array}{l}\text { Nikka Unggul } \\
\text { Prasojo }\end{array}$ & 60 \\
\hline
\end{tabular}

Table 2. Data for Munadloroh Score

\begin{tabular}{|c|c|c|c|}
\hline No. & $\begin{array}{l}\text { Student } \\
\text { Number }\end{array}$ & Name & $\begin{array}{l}\text { Muna } \\
\text { dloroh }\end{array}$ \\
\hline 1 & 2018082001 & Elya Mawarni & 80.67 \\
\hline 2 & 2018082002 & $\begin{array}{l}\text { Autsaqani } \\
\text { Fllubudiyati }\end{array}$ & 76.67 \\
\hline 3 & 2018082003 & $\begin{array}{l}\text { Ahmad Bahrum } \\
\text { Madoan }\end{array}$ & 72.07 \\
\hline 4 & 2018082005 & Khitoh Fatonah & 78.33 \\
\hline 5 & 2018082006 & Umi Nur Hidayah & 74.33 \\
\hline 6 & 2018082007 & $\begin{array}{l}\text { Nurarsyi } \\
\text { Nugrahawati }\end{array}$ & 84.33 \\
\hline 7 & 2018082008 & Khairunnisa & 73.67 \\
\hline 8 & 2018082009 & Indra Adisaputra & 92.07 \\
\hline 9 & 20180820010 & $\begin{array}{l}\text { Paramudita Arbi } \\
\text { Nugroho }\end{array}$ & 82.67 \\
\hline 10 & 20180820011 & $\begin{array}{l}\text { Syifa Miftahul } \\
\text { Jannah }\end{array}$ & 62.00 \\
\hline 11 & 20180820012 & $\begin{array}{l}\text { Laura Oktarianti } \\
\text { Nasution }\end{array}$ & 79.00 \\
\hline 12 & 20180820013 & $\begin{array}{l}\text { Irawati Khoviva } \\
\text { Duru }\end{array}$ & 78.67 \\
\hline 13 & 20180820014 & Zyubhaida & 90.00 \\
\hline 14 & 20180820018 & Fikri Aulia Madani & 82.00 \\
\hline 15 & 20180820019 & Eza Qurnia Hayati & 81.33 \\
\hline 16 & 20180820020 & Sari Arya Ningrum & 73.67 \\
\hline 17 & 20180820021 & $\begin{array}{l}\text { Moh Fikri Akbar } \\
\text { Arasy }\end{array}$ & 29.47 \\
\hline 18 & 20180820022 & Duratul Jinan & 76.33 \\
\hline 19 & 20180820025 & $\begin{array}{l}\text { Rahmawati } \\
\text { Indriyani }\end{array}$ & 78.73 \\
\hline
\end{tabular}




\begin{tabular}{|l|l|l|l|}
\hline 20 & 20180820027 & Farah Tazkia & 72.33 \\
\hline 21 & 20180820028 & Linda Wati & 85.67 \\
\hline 22 & 20180820029 & $\begin{array}{l}\text { Urfa Zuyina } \\
\text { Alfarisi }\end{array}$ & 83.87 \\
\hline 23 & 20180820030 & $\begin{array}{l}\text { Muhammad } \\
\text { Maulud Ikhsan } \\
\text { Nabawi }\end{array}$ & 81.20 \\
\hline 24 & 20180820031 & Rizal Yusuf Hanifa & 77.07 \\
\hline 25 & 20180820033 & $\begin{array}{l}\text { Nikka Unggul } \\
\text { Prasojo }\end{array}$ & 63.07 \\
\hline
\end{tabular}

To identify the factors that hindered the debate, the researchers conducted direct interviews with students. Based on the interview, the researchers revealed the various factors that could hinder the students from joining an Arabic debate, namely:

1. Techniques in debate

2. Rhetoric in debate

3. Procedure for debate

4. Lack of access to practice Arabic Language and Arabic private class

5. The application of Arabic grammatical structures

6. Difficulty in understanding the debate materials

7. Less supportive environment to speak Arabic

8. How to present an argument in a debate

9. Lack of support and motivation

10. Lack of scientific insight

11. Difficulty in self-positioning in the uncomfortable environment

12. Feeling inferior towards advanced opponents

13. Lack of time practicing

14. Arabic dialect is different from the Indonesian dialect

15. How to develop materials

16. How to strengthen an argument

This study used the product-moment correlation formula to find the relationship between the independent and dependent variables to determine whether there was a relationship between vocabulary mastery and the Arabic language students' debating skills of the Arabic language education study program UMY 2018. The advantage of using Pearson's $r$ is that it is a simple way to assess the association between two variables; whether they share variance (covary), if the relationship is positive or negative, and the degree to which they correlate [6]. In this study, the independent variable was the mastery of Arabic words, and the dependent variable was the ability in Arabic language debate.
Table 4

Correlations
\begin{tabular}{|ll|l|l|}
\hline & KOSAKATA & MUNADLOROH \\
\hline VOCABULARY & Pearson Correlation & 1 & $866^{*}$ \\
& Sig. (2-tailed) & & 000 \\
N & 25 & 25 \\
\hline MUNADLOROH & Pearson Correlation & $866^{*}$ & 1 \\
& Sig. (2-tailed) & 000 & \\
N & 25 & 25 \\
\hline$* *$ Correlation is significant at the 0.01 level (2-tailed).
\end{tabular}

The table above or in the correlation table results from the calculation of the correlation by using SPSS. It shows that the correlation value between vocabulary mastery and the ability to debate in Arabic is 0.866 . The number indicates a high correlation between vocabulary mastery and the Arabic language debating skills of the Arabic language education study program UMY 2018.

Table 5. Guidelines for Correlation Degree

\begin{tabular}{|l|l|}
\hline Coefficient Interval & $\begin{array}{l}\text { Correlation } \\
\text { Level }\end{array}$ \\
\hline Pearson correlation value $0,00 \mathrm{~s} / \mathrm{d} 0,20$ & No correlation \\
\hline Pearson correlation value $0,21 \mathrm{~s} / \mathrm{d} 0,40$ & Low correlation \\
\hline Pearson correlation value $0,41 \mathrm{~s} / \mathrm{d} 0,60$ & $\begin{array}{l}\text { Moderate } \\
\text { correlation }\end{array}$ \\
\hline Parson correlation value $0,61 \mathrm{~s} / \mathrm{d} 0,80$ & High correlation \\
\hline Pearson correlation value $0,81 \mathrm{~s} / \mathrm{d} 1,00$ & $\begin{array}{l}\text { Perfect } \\
\text { correlation }\end{array}$ \\
\hline
\end{tabular}

The table above is a table of interpretation of the correlation coefficient, Muhidin (2009), also the relationship's level from the results of previous calculations [7]. In the correlation calculation table, the Pearson correlation in this calculation shows a result of 0.866 and a sig value. ( 2 tailed) of 0.000 . If sig. ( 2 tailed) is $<0.05$, then the relationship between the two variables is significant. Meanwhile, if sig. is >0.05 (2 tailed), the relationship between the two variables is insignificant.

The above calculations reveal that the correlation value between vocabulary mastery and Arabic language debate in the Arabic language education UMY 2018 students is 0.886 . The correlation value shows a perfect correlation between vocabulary mastery with Arabic language debating skills.

Meanwhile, the number of sig. ( 2 tailed) between the variables of vocabulary mastery and Arabic language, debating ability is 0,000 . The number of sig. ( 2 tailed) is $<0.5$; thus, it shows that the relationship between the two variables is significant.

To find out what factors hindered the debate, the researchers conducted direct interviews with students. The researchers obtained the data explaining many factors inhibiting student debating skills based on the interview results. To make it easier for readers, the researcher 
summarizes the inhibiting factors into four factors, namely:

1. The material or theme in the debate

The theme or material in the debate is an issue that will be discussed and developed in the debate [8]. The motions used in the debate are taken from actual problems to increase the participants' critical feelings and curiosity from the participants themselves.

Students find it challenging to sort out the existing material's content in terms of material or motion. As the debate material is actual issues, debating participants frequently understand the existing material and lack insight.

\section{Debating Participants}

Debating participants are actively involved in conveying their opinions or ideas directly in the debate forum. In the debate, participants function as communicators who are expected to convince listeners through their opinions and ideas [8].

- Ethos

Ethos in communication science is the essential skill that a speaker must-have. Thus, he can convince and become a source of trust for his listeners. In terms of ethos, some students felt that they could not express their opinion correctly due to several factors, including a sense of inferiority to other students or their debate opponents.

\section{- Pothos}

Pothos is the ability to convey and touch the listeners' feelings. Based on researchers' interviews, 2 to 3 students felt they could not convey their arguments properly. They found it challenging to use dialect or good intonation in Arabic.

- Logos

Logos is the speaker's ability to convey his opinion or ideas logically and easily understood by the listener. In terms of logos, students' difficulties were concluding the material or conveying their opinions and arguments to the audience to quickly understand what they meant. They also found it challenging to provide rebuttals to their opponents in the debate as sometimes they found it difficult to understand what the opponent meant.

\section{Environment}

In the field of education, many factors support the success of the educational process. One of the factors is the environmental factor. However, apart from being a supporting factor in education, the environment can also inhibit success.

Likewise, in debate learning, the environment can also be a supporting factor of success or vice versa. Based on the interviews conducted by researchers with students, some of the students also answered that they found it difficult to argue using Arabic due to less supportive environmental factors. It refers to an environment that rarely uses Arabic as a language when communicating. Therefore, it resulted in the students' difficulty when required to debate using Arabic as the medium of instruction.

\section{Language}

Language has many vital components. One of them is grammatical structure. Based on the previous interviews, besides the vocabulary mastery factor, the respondents also found it challenging to use the grammatical structure as it could affect the meaning or meaning of what is explained by the speaker when there is an error in the use of grammar.

\section{CONCLUSION}

Based on the results, there is a significant correlation between vocabulary mastery and the Arabic language debating skills in students of the Arabic language education study program UMY 2018 with the perfect Pearson correlation result. Furthermore, the number of sig. ( 2 tailed) resulting from these calculations was 0.000 , explaining that the number sig. ( 2 tailed) $<0.5$. It indicates that the relationship between the two variables was significant.

Moreover, based on the results of interviews conducted by researchers, it can be concluded that there were several inhibiting factors in the Arabic language debating skills of Arabic language students, including:

\section{The material factor or theme in the debate}

The students found it challenging to sort out the existing material's content in terms of material or motion. As the debate material is actual issues, debating participants frequently had difficulty understanding the existing material and lack of insight. Apart from this, some students also found it challenging to develop the material received and strengthen the material.

\section{Debating Participants}

In terms of ethos, some students felt that they could not express their opinion correctly due to several factors, including a sense of inferiority to other students or their debating opponents. In terms of pothos, it is not enough to convey the argument well. They found it challenging to use dialects or good intonation in Arabic. In terms of logos, students' difficulties included concluding the material or conveying their opinions and arguments to the audience. They also found it challenging to provide rebuttals to their opponents in the debate and understand what the opponents meant.

\section{Environment}

Based on the interviews conducted by researchers with students, some of the students also revealed that they found it difficult to argue using Arabic due to less 
supportive environmental factors. It included an environment that rarely used Arabic as a language when they were communicating, so that students also found it difficult when they were required to debate using Arabic as the medium of instruction.

\section{Language}

Based on the previous interviews, apart from the vocabulary mastery factor, the respondents also found it challenging to use the grammatical structure. Furthermore, based on the result of this study, the researchers make the following suggestions.

For lecturers who teach courses, it is expected that they can increase the number of debating exercises for students. Thus, the students can get used to conducting debates and developing material in Arabic language debates.

It is suggested that students start to practice the Arabic language in communication and spend more time practicing in developing material and strengthening arguments in the debating context.

\section{AUTHORS' CONTRIBUTIONS}

In this study, the researchers collected data, analyzed, and made conclusions from the data. However, in conducting the study, the researchers were fully assisted by Nasita Dara Maula.

\section{ACKNOWLEDGMENT}

Special thanks to the Department of Arabic Language Education, Faculty of Language Education and LP3M Universitas Muhammadiyah Yogyakarta for providing financial support for completing this research.

\section{REFERENCES}

[1] Fahrurozi, Rachmadtullah, Hasanah U, The influence of reading interests, vocabulary mastery and critical thinking on reading comprehension in elementary school students., International Journal of Psychosocial Rehabilitation (2020) 24 (8) 1630 1640

[2] Khoirotun Ni'mah, “Korelasi Penguasaan Kosa Kata Bahasa Arab Dengan Kemampuan Berpidato Bahasa Arab Mahasiswa PBA Unisda Lamongan" Dar El-Ilmi: Jurnal Studi Keagamaan, pendidikan dan humaniora, Vol 4, No 1, April 2017, hlm.123

[3] Melfin. Silberman, "Activ Learning 101 Cara Belajar Siswa Aktif”, (Bandung:Nusa Media, 2006)

[4] Sugiyono, "Metode Penelitian Kuantitatifdan $R \& D ”$, (Bandung: Alfabeta, 2011).

[5] Ahmad Tanzeh, "Pengantar Metode Penelitian", (Yogyakarta: Sukses Offest 2009)
[6] Jennifer Chee, Pearson's Product Moment Correlation: Sample Analysis, University of Hawaii at Manoa School of Nursing, ResearchGate, 31 Desember 2018

[7] Sambas Ali Muhidin, "Analisis Korelasi, Regresi dan Jalur dalam Penelitian”, (Bandung: CV Pustaka Setia, 2009).

[8] Zainul Arifin, Urgensi Penerapan Metode Pembelajaran Debat Aktif Dalam Meningkatkan Keberanian Berbicara Siswa Pada Bidang Studi Fiqih di Madrasah Aliyah Darussalam Kelas 2 Surabaya, skripsi, 2007. 